\title{
THE
}

1989

\section{Sea Beam survey of an active strike-slip fault: The San Clemente fault in the California Continental Borderland}

\author{
Mark R. Legg \\ Bruce P. Luyendyk \\ Jacqueline Mammerickx \\ Christian de Moustier \\ Robert C. Tyce \\ University of Rhode Island, robtyce@uri.edu
}

Follow this and additional works at: https://digitalcommons.uri.edu/gsofacpubs

Terms of Use

All rights reserved under copyright.

\section{Citation/Publisher Attribution}

Legg, M. R., B. P. Luyendyk, J. Mammerickx, C. deMoustier, and R. C. Tyce (1989), Sea Beam survey of an active strike-slip fault: The San Clemente fault in the California Continental Borderland, J. Geophys. Res., 94(B2), 1727-1744, doi: 10.1029/JB094iB02p01727.

Available at: http://dx.doi.org/10.1029/JB094iB02p01727

This Article is brought to you for free and open access by the Graduate School of Oceanography at DigitalCommons@URI. It has been accepted for inclusion in Graduate School of Oceanography Faculty Publications by an authorized administrator of DigitalCommons@URI. For more information, please contact digitalcommons-group@uri.edu. 
SEA BEAM SURVEY OF AN ACTIVE STRIKE-SLIP FAULT: THE SAN CLEMENTE FAULT IN THE CALIFORNIA CONTINENTAL BORDERLAND

Mark R. Legg ${ }^{1}$ and Bruce P. Luyendyk

Department of Geological Sciences, University of California, Santa Barbara

Jacqueline Mammerickx and Christian de Moustier

Scripps Institution of Oceanography, University of Galifornia, San Diego, La Jolla

Robert C. Tyce

Graduate School of Oceanography, University of Rhode Island, Kingston

\begin{abstract}
The San Clemente fault, located in the California Continental Borderland, is an active, northwest trending, right-lateral, wrench fault. Sea Beam data are used to map the major tectonic landforms associated with active submarine faulting in detail unavailable using conventional echo-sounding or seismic reflection data. In the area between North San Clemente Basin and Fortymile Bank, the major late Cenozoic faults are delineated by alignments of numerous tectonic landforms, including scarps, linear trenches, benches, and sags. Character and spatial patterns of these landforms are consistent with dextral wrench faulting, although vertical offsets may be substantial locally. The main trace of the San Clemente fault cuts a straight path directly across the rugged topography of the region, evidence of a steeply dipping fault surface. Basins or sags located at each right step in the en echelon pattern of faults are manifestations of pull-apart basin development in a right-slip fault zone. Seismic reflection profiles show offset reflectors and a graben in late Quaternary turbidites of the Navy Fan, where the fault zone follows a more northerly trend. Modern tectonic activity along the San Clemente fault zone is demonstrated by numerous earthquakes with epicenters located along the fault's trend. The average strike of the San Clemente fault is parallel to the predicted Pacific-North American relative plate motion vector at this location. Therefore we conclude that the San Clemente fault zone is a part of the broad Pacific-North American transform plate boundary and that the southern California region may be considered as a broad shear zone.
\end{abstract}

\section{Introduction}

This paper describes a detailed investigation, using the Sea Beam system [Renard and Allenou, 1979], of a $50-\mathrm{km}$ length of the San clemente fault zone in a region of rugged bathymetry offshore California (Figures 1 and 2). Additional marine geophysical data (Figure 3), including high-resolution seismic reflection profiles using both $3.5-\mathrm{kHz}$ and air gun sources, near bottom, i.e., Deep Tow

'Now at NTS Engineering, Long Beach, California. Copyright 1989 by the American Geophysical Union.

Paper number $88 \mathrm{JB} 03672$.

$0148-0227 / 89 / 88 \mathrm{JB}-03672 \$ 05.00$
[Spiess and Tyce, 1973] subbottom profiler, magnetometer, and side-scan sonar records, and ocean surface total magnetic field intensity measurements, were used to assist in the interpretations of the seafloor structure.

Bathymetric maps were used to infer that the ridge and basin topography of the California Continental Borderland is structurally controlled [Shepard and Emery, 1941]. It was suggested that major northwest trending faults, similar to those observed on land nearby, are delineated by long, linear, steep escarpments which bound the offshore ridge and island blocks. For example, the San Clemente fault zone is delineated by the prominent escarpment along the eastern flank of San Clemente Island (Figures 1 and 2a). More recent oceanographic studies used seismic reflection profiles to map offshore geologic structure and confirm the interpretations made from bathymetry [e.g., Moore, 1969; Ridlon, 1969; Vedder et a1.. 1974].

In areas of rugged seafloor topography, detailed mapping of geologic structure using seismic reflection data is difficult because of the relatively wide beam width of the acoustic systems. Subbottom features and, in many instances, the bottom reflection itself directly beneath the ship may not be recorded or may be obscured by acoustic reflections from adjacent topography. Narrow-beam Sea Beam data provide detailed mapping of the surficial expression of major tectonic features in such areas.

\section{Regional Tectonic Framework}

Late Genozoic tectonic history of the southern California region is dominated by interaction between the Pacific and North American tectonic plates [Atwater, 1970; Engebretson et al., 1985]. The San Andreas fault system [Crowell, 1962] consists of several major, northwest trending, dextral, wrench fault zones; it forms the broad continental transform fault boundary between the Pacific and North American plates (Figure 1). This broad transform fault boundary is inferred to extend offshore and include major northwest trending faults such as the San Clemente [Legg and Kennedy, 1979]. Although some investigators proposed that Miocene east-west extension and block faulting account for California continental Borderland structure and physiography [Yeats, 1976], right-lateral shear along major, northwesttrending, late Cenozoic fault zones is recognized within this offshore region [Junger, 1976; Greene et al.. 1979; Legg and Kennedy, 1979; Crouch, 1981; Legg, 1985]. 


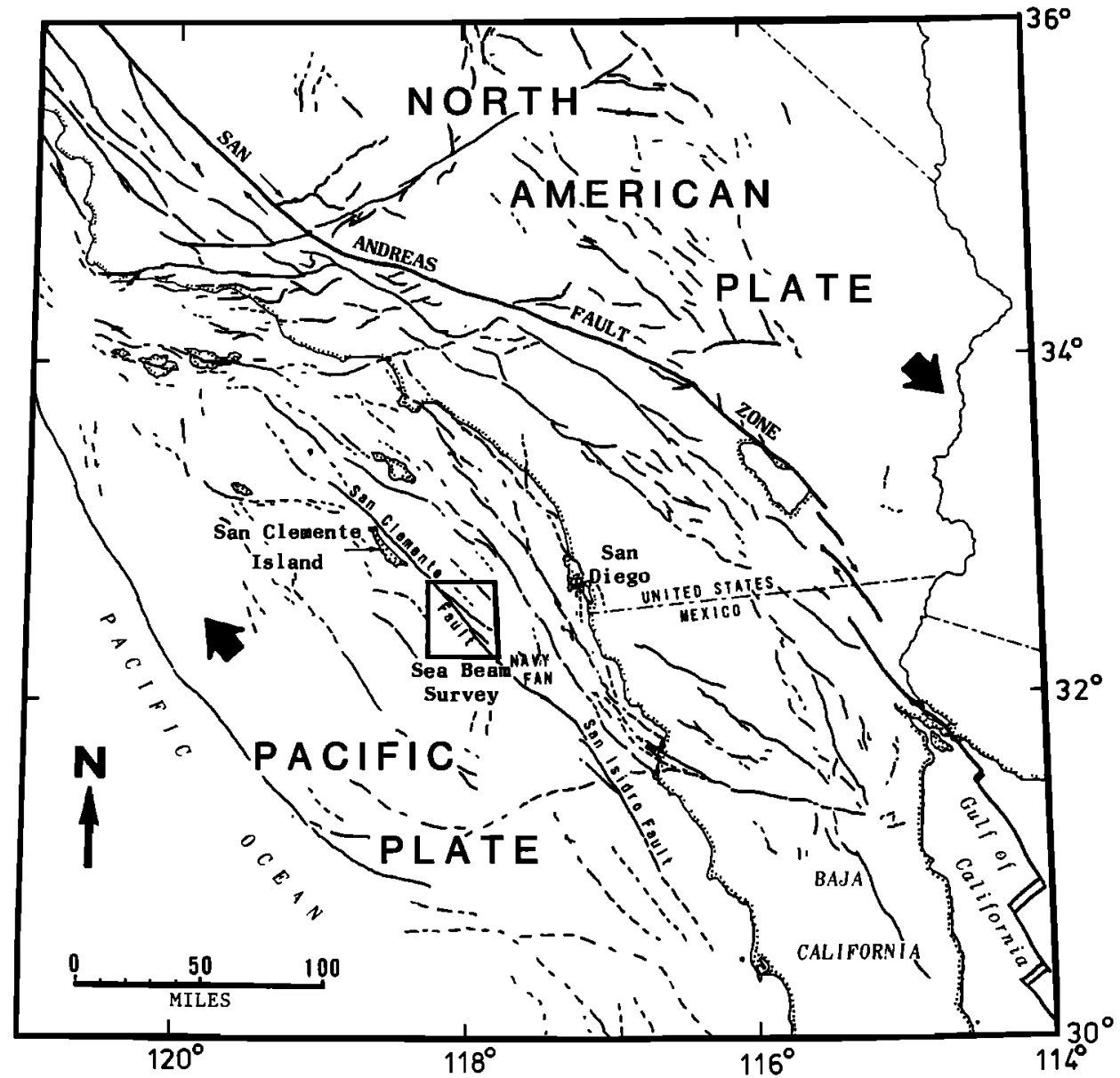

Fig. 1. Regional reference map showing plate tectonic framework of the southern California area and location of this study. The North American-Pacific tectonic plate boundary in this area is modeled as a dextral transform fault with a strike of about $N 40^{\circ} \mathrm{W}$ at the latitude of the Sea Beam survey. Major faults of the San Andreas fault system in the southern California and northern Baja California region are delineated. This study focuses upon the San Clemente fault which is part of the San Clemente-San Isidro fault zone [Legg and Kennedy, 1979; Legg, 1985].

No piercing points displaced by major fault zones in the California Continental Borderland have been identified to date, although many hypotheses of substantial lateral slip have been proposed. Most proponents of large lateral displacements maintain that these occurred during Miocene time [Howe11 et a1., 1974a, b; Howell, 1976; Yeats, 1976; Crouch, 1979; Howell and Link, 1983; Kies and Abbott, 1983] citing offset of possibly correlative geologic markers such as the Eocene conglomeratic suite found in the San Diego area and offshore, more than $100 \mathrm{~km}$ to the northwest, on the northern Channel Islands.

Estimates of post-Miocene displacement on California Continental Borderland faults are generally small [Junger, 1976; A. Junger and J. Vedder, personal communication, 1980]. Observing that San Clemente Island is bounded to the east by a major escarpment and Fortymile Bank is bounded to the west by a similar escarpment aligned along the San Clemente Canyon, Shepard and Emery [1941] propose $40 \mathrm{~km}$ (25 miles) of right-slip along the San clemente fault zone; this would restore Fortymile Bank to a position adjacent to San Clemente Island. Axes of submarine canyons which cross major fault zones in the region are also inferred to be later- ally offset [Greene et a1., 1979; Legg and Kennedy, 1979; Kennedy et al., 1980; Legg, 1985]. Some investigators postulate that a significant proportion (208-308) of the overall Pacific-North American relative plate motion occurs on offshore faults in the southern California region [Anderson, 1979; Weldon and Sieh, 1985; Hornafius et al., 1986; Weldon and Humphreys, 1986]. Other investigators propose that slip rates on these offshore fault zones are minor (Bird and Rosenstock, 1984; T.H. Jordan et al., unpublished manuscript, 1986].

\section{Methods}

\section{Narrow-Beam Echo Sounding}

Resolution of small-scale ( $\leqq 1 \mathrm{~km})$ seafloor topography requires narrow-beam acoustic imaging systems. Long-range side scan sonars towed at relatively shallow depths are used to map seafloor morphology over large areas (e.g., GLORIA, [Searle, 1979; Field et al., 1984] and Sea MARC I and II [Batiza et a1., 1984; Silver et al., 1986; Kastens et al., 1986]). Sea Beam is a multiple narrow-beam echo sounder, with echo processor, which generates contour maps of the seafloor while the ship is 


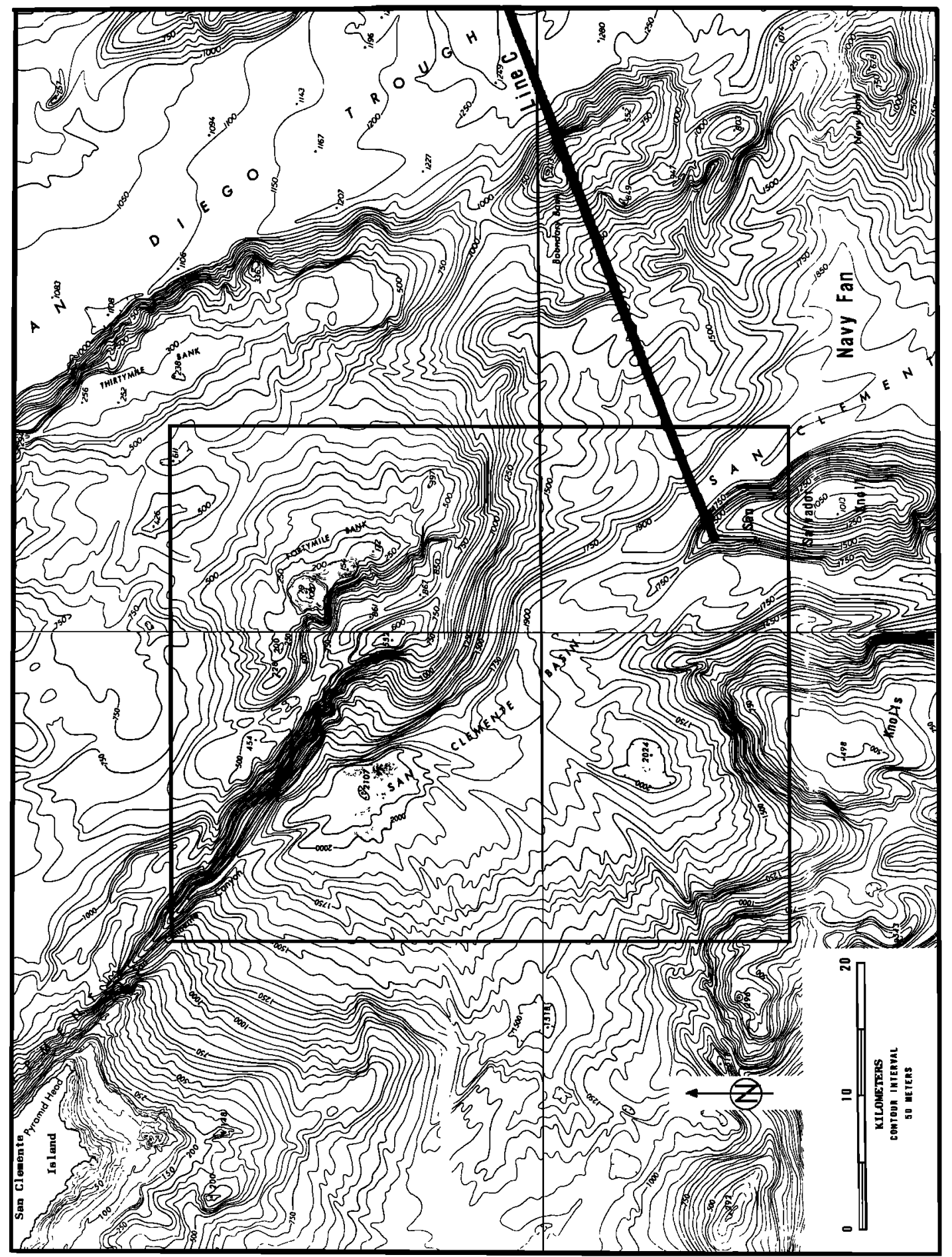

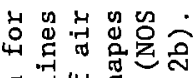

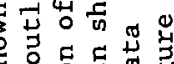
2.웡

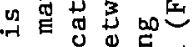
舟.

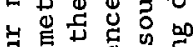

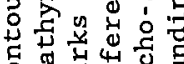

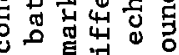

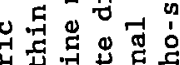
प

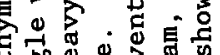

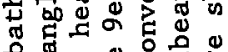

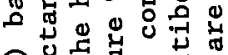

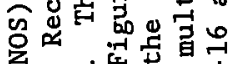
\&

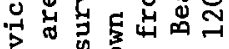
क.

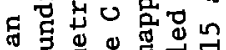
\& ๆ

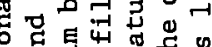
\%

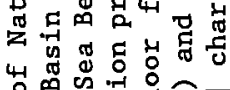

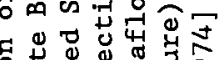

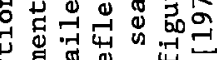
过

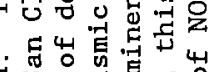
तु क कि

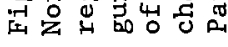




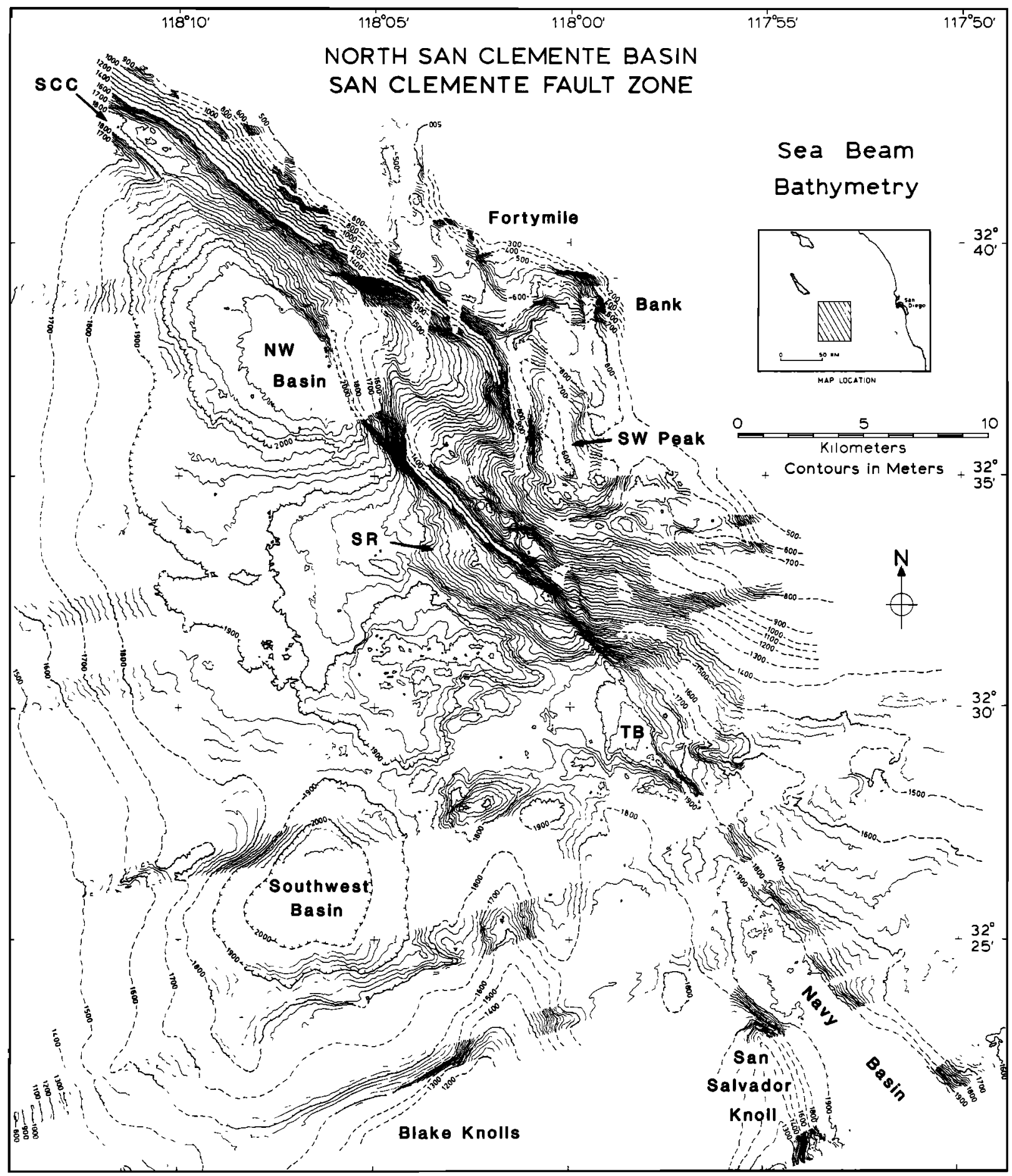

Fig. 2b. Sea Beam bathymetric map of the San Clemente fault zone in the vicinity of Fortymile Bank and North San Clemente Basin. Contour interval is $20 \mathrm{~m}$ in areas of Sea Beam swath coverage. Contours for $100-\mathrm{m}$ intervals are identified by tick marks and labeled with the depth, assuming a constant acoustic velocity of $1500 \mathrm{~m} / \mathrm{s}$. Tick marks point in the downslope direction. In areas not crossed by the Sea Beam swaths, 100 -m contours were extrapolated by hand and are shown by dashed lines. Note that in areas of very steep slopes, some contours have been deleted to improve map legibility (see Plate 4 of Legg [1985] for complete contour map of the region). Locations and full names of the major geomorphic features described in the text are shown in Figure 3. 


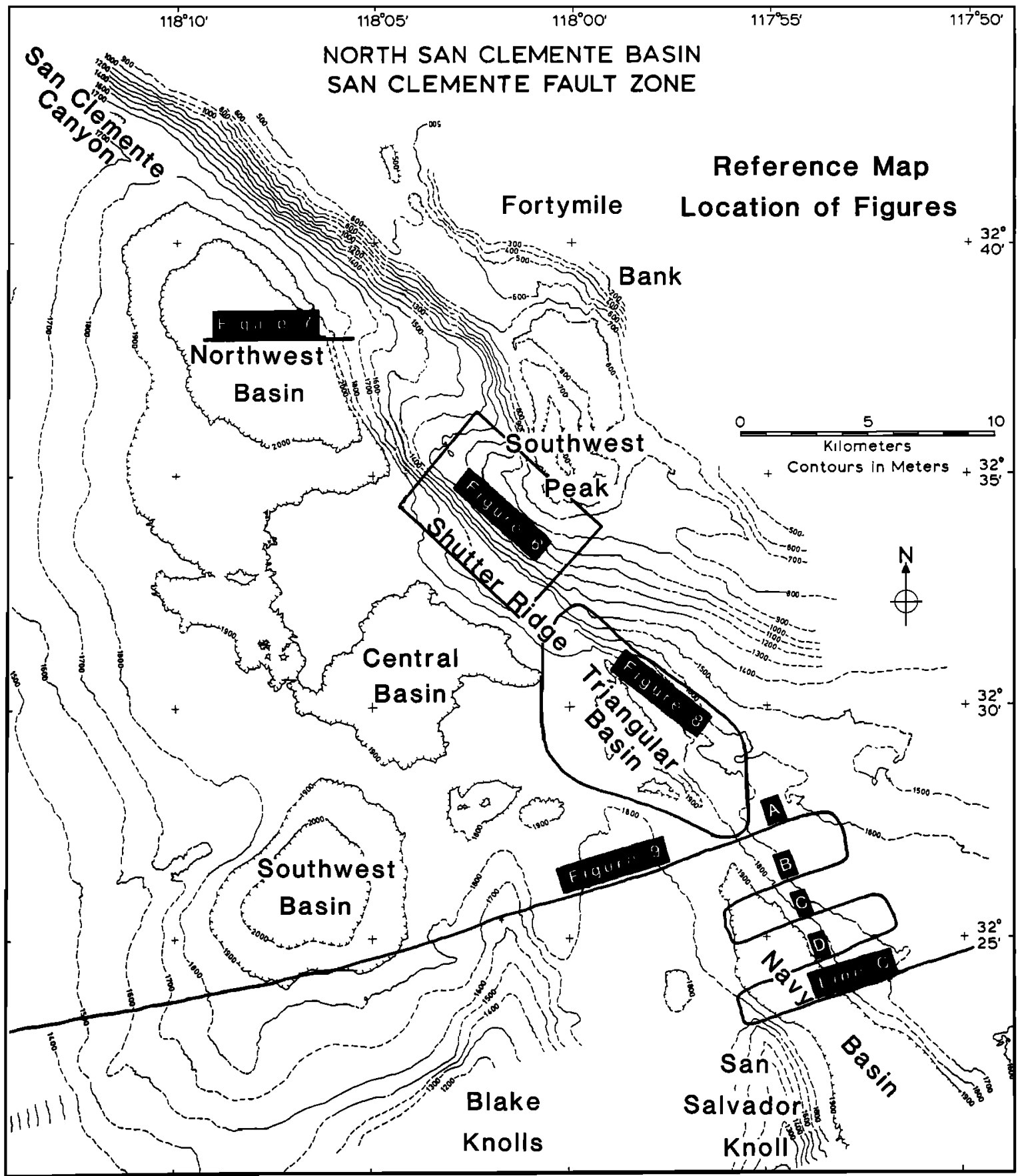

Fig. 3. Location map of the major bathymetric features, seismic reflection profiles, and other detailed figures shown in this study. Figure numbers are identified for location of each figure with respect to the regional bathymetry.

underway [Renard and Allenou, 1979]. The multiple narrow-beam character of the Sea Beam system is important for detailed mapping of rugged seafloor topography, and many important morphologic features, including offset spreading centers, oceanic transform fault zones, submarine canyons and channels, seamount craters and calderas, and submarine landslides, have been imaged with the system [Renard and Allenou, 1979; Batiza et al., 1984; Edwards et al., 1984; Macdonald et a1., 1984; Mammerickx, 1984; Gallo et al., 1986; Madsen et al., 1986].

\section{Sea Beam Data Processing and Analysis}

Lateral resolution of seafloor topography with Sea Beam in the area of this study is approximately 50-100 m, although the true shape of such small features may not be determined. Many small features apparent in the flat areas may not be real, although some minor relief in these areas is evident on the center beam ( $12 \mathrm{kHz}$ ) monitor records. Mean accuracy for the contoured depth is about 10-15 m [Renard and Allenou, 1979], although the 


\section{BLOCK DIAGRAM SHOWING LANDFORMS PRODUCED ALONG RECENTLY ACTIVE FAULTS}
A. SCARP
B. FACETED RIDGE
C. Linear trench
D. LIMEAR VALLEY
E. LINEAR RIDGE
F. SHUTTERRIDGE
c. NOTCH
H. HiLLside VALLEY
I. ВENCH
J. OFFSET CHANNEL
K. SPRING
L. Deflected Channel.
M. OFFSET RIDGE
N. DEPRESSION (SAG POND)
O. DEPRESSION (BASIN)
P. PONDED SEDIMENT

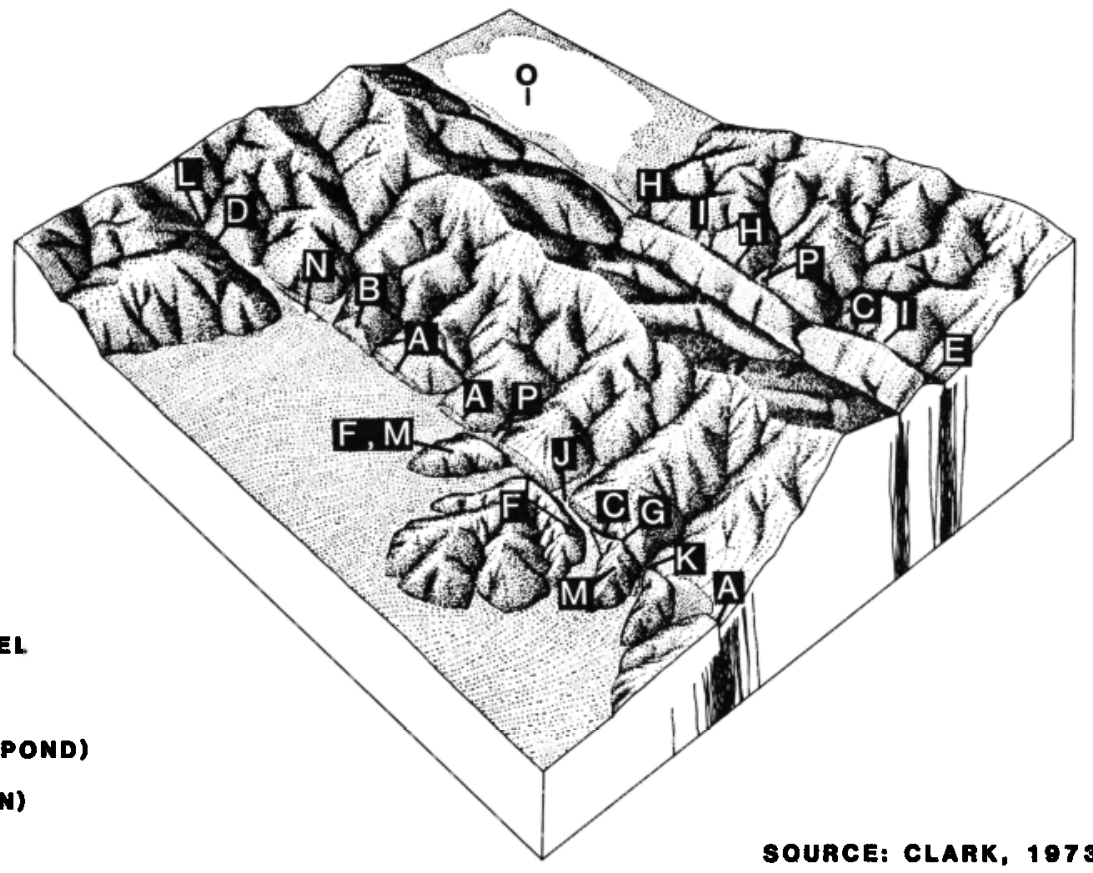

Fig. 4. Block diagram showing tectonic landforms commonly observed along recently active, terrestrial (subaerial), strike-slip faults. Many of these features may be observed along the submarine San Clemente fault zone in the area of this study. Some of the more important features identified include: scarps (A), linear trenches (C), linear valleys (D), linear ridges (E), benches (I), depressions or sags (N), and basins (O). Features similar to other important tectonic landforms are observed in the area, but the available data are insufficient to determine their origins.

depth accuracy of the center beam, monitored on an analog recorder, is about 2-3 $\mathrm{m}$.

Accurate navigation of the ship is necessary to produce accurate bathymetric maps. Because data from several Sea Beam test cruises were compiled in this study and each cruise used different navigational systems with varied accuracies, special effort was made to align all of the Sea Beam contours to those of the most accurately navigated Sea Beam swaths [Legg, 1985]. Most of the area was surveyed using LORAN-C radio-navigation, with frequent position fixes, combined with occasional transit satellite and radar positioning. The final bathymetric chart (Figure 2b; cf. Plate 4 of Legg [1985]) was hand drafted at a $20-\mathrm{m}$ contour interval by aligning computer generated plots of the various Sea Beam cruise data to obtain a "best" fit of the overlapping contours. Overall geographic position accuracy over most of the area of the final map is estimated to be better than $500 \mathrm{~m}$ in absolute position and better than $200 \mathrm{~m}$ in relative position.

\section{Discussion}

\section{Tectonic Landforms Along Recently Active Faults}

Land-based studies rely upon recognition of tectonic landforms to identify, trace, and characterize active faults [Lawson et al., 1908; Slemmons, 1977; Patterson, 1979; Davis, 1983]. Major landforms that are produced along active strike-slip faults and that are large enough to be imaged by Sea Beam are shown in Figure 4. Alignment of numerous tectonic landforms is inferred to identify an active fault zone. Additional data, such as the seismic reflection profiles that show offset subbottom reflectors, help to confirm tectonic origins for these seafloor lineaments. Minor features, such as fissures, small scarps, and fault traces commonly formed during single tectonic events, have been identified on the seafloor by other means (for example, bottom photography).

Tectonic Landforms Along the San Clemente Fault Zone

Scarps are the most common tectonic landforms shown by the Sea Beam contours in the mapped area (Figures $2 b$ and 5 ). Tectonic scarps are linear and generally have the greatest slope gradients. Other scarps, of possible nontectonic origin such as landslide or slump scarps, are generally more curvilinear or arcuate in plan view. Such scarps often occur along oversteepened slopes associated with basement fault zones. Some scarps may be created by seafloor currents, such as those along channels where turbidity currents have been active. Tectonic scarps, like those along San Clemente Canyon (SCC, Figures $2 \mathrm{~b}$ and 5 ), may be maintained or steepened by erosive seafloor currents.

In detail, the major tectonic scarps, or escarpments, are shown to be composite in nature, with more than one steep section along the slope. Individual scarps, or especially steep sections within 


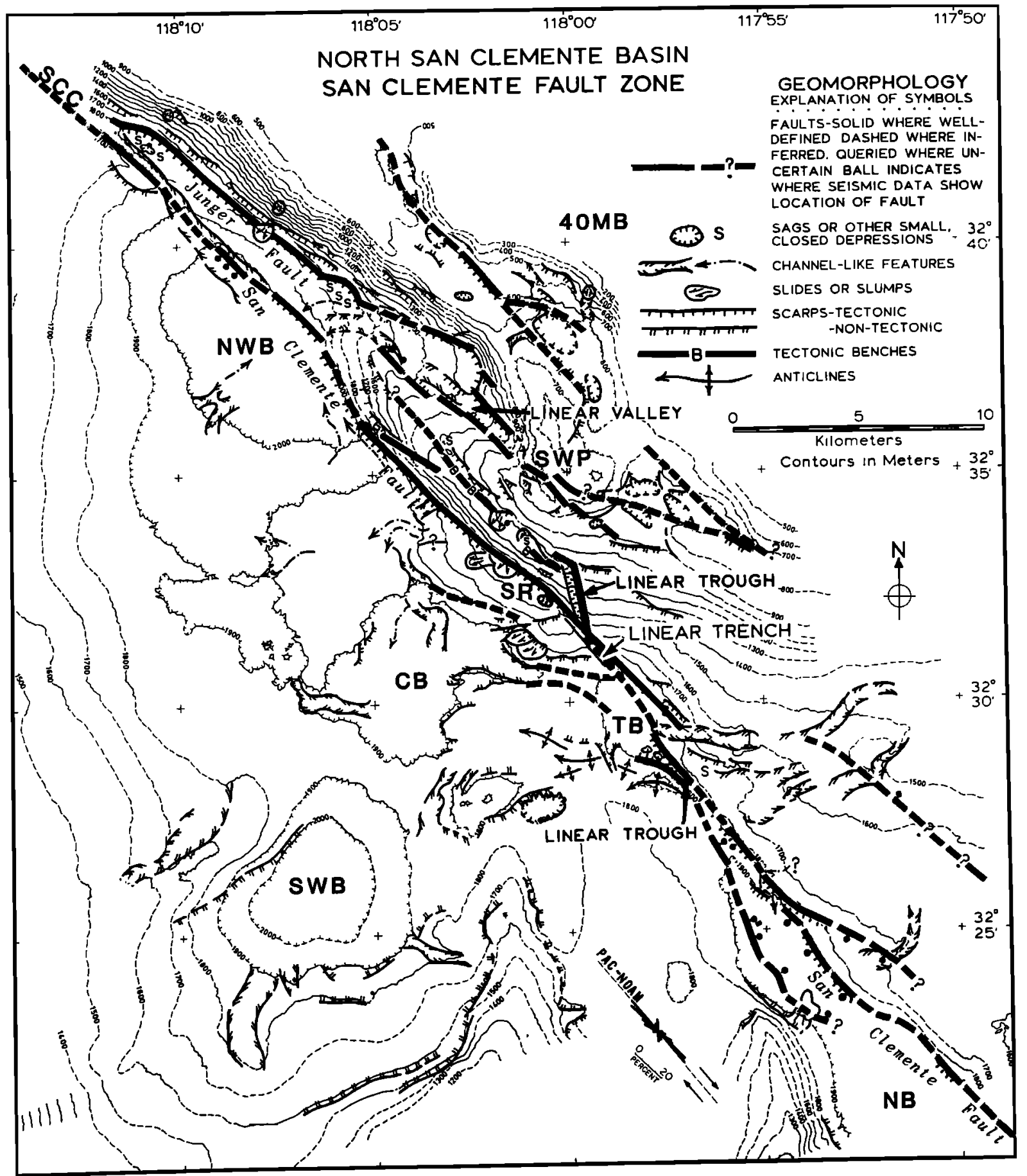

Fig. 5. Tectonic geomorphology of the San Clemente fault zone in the vicinity of Fortymile Bank and North San Clemente Basin. Map shown is a simplified version of the large-scale original presented as Plate 5 of Legg [1985]. Tectonic and other geomorphic features interpreted from the Sea Beam data of this study are shown (cf. Plate 5 of Legg [1985]). Most of the features plotted were identified solely from the Sea Beam bathymetric contours (Figure $2 \mathrm{~b}$ and Plate 4 of Legg [1985]). Major fault traces are delineated by scarps, aligned sags, and other lineaments. Faults identified on seismic reflection profiles are labeled with a special symbol at the location where the profile crosses the fault. The ball and bar symbol shows which side of the fault is relatively down. Inset shows rose diagram of fault trends in the study area. Dashed line marked PAC-NOAM shows predicted trend of transform faults for the Pacific-North American plate boundary at this location [after Minster and Jordan, 1978]. 


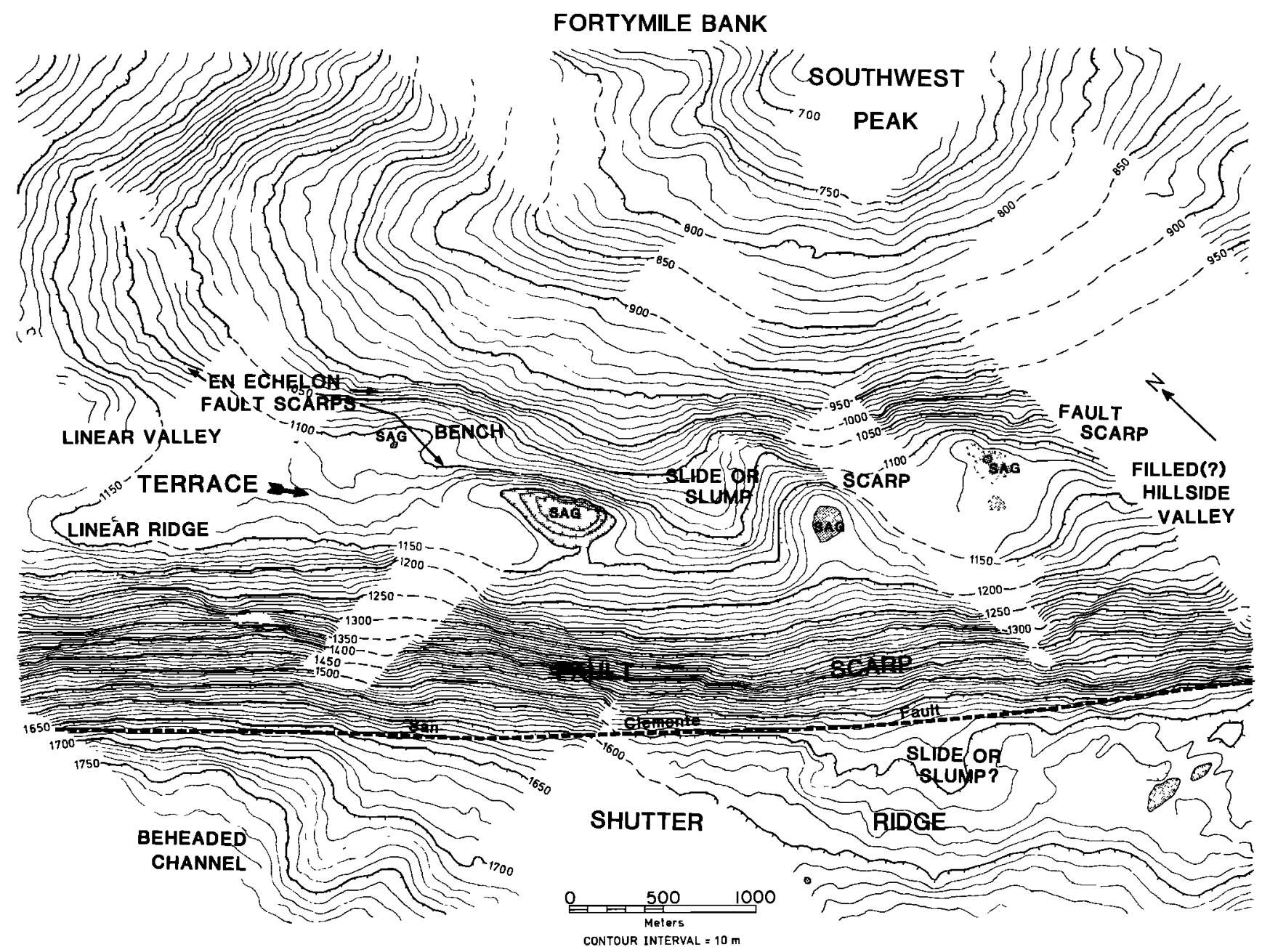

\section{NORTH SAN CLEMENTE BASIN}

Fig. 6. Portion of Sea Beam area shown in detail using the original swath charts (real-time Sea Beam data) contoured at a 10-m interval. Many tectonic landforms similar to those shown in Figure 4 are identified. The inferred main trace (principal displacement zone) of the San clemente fault is shown by the dashed line. Sags or smal1 closed depressions are shown by shading. (See Figure 3 for location of this figure.)

a major escarpment shown by Sea Beam contours, may delineate single fault traces or very narrow fault zones. Scarps mapped by Sea Beam are probably the result of many individual fault movements and represent a long-term average of the fault slip. Although these scarps may represent an assemblage of faults, the locations of the inferred fault traces are mapped at the base of the steepest part of the individual scarps, not at the base of possible debris or talus slopes. On land, the fault traces are typically found near the middle of the individual scarps. If the scarp profile is sigmoidal [Hanks et al., 1984], then the middle of the scarp is at the inflection point, which is identical to the base of the steepest part of the scarp. Fault traces are also delineated by narrow linear depressions and alignments of small closed depressions.

The set of fault traces mapped along the scarps and other tectonic features throughout the area is called the San Clemente fault zone. Numerous scarps, linear ridges, valleys and trenches, aligned depressions, and larger, fault-bounded basins delineate the youthful fault traces or zones
(Figures 2, 5, and 6). Larger depressions or basins may extend beyond the zone of faulting; however, they may be of tectonic origin, like pull-apart basins and grabens. A narrow throughgoing lineament of tectonic landforms, the San Clemente fault (Figure 5), separates the elevated basement structure of Fortymile Bank from the deep, irregularly shaped, North San Clemente Basin (Figures 2 and 5 ). In this area, the San Clemente fault can be divided into three roughly linear segments marked by major escarpments.

Northern Segment: San Clemente Canyon and Northwest Basin

The San Clemente fault is mapped along the northeast margin of Northwest Basin (NWB) where a sharp change in slope gradient occurs along a linear trend (Figures $2 b$ and 5 ). The fault trace is mapped along this lineament because high-resolution $(3.5 \mathrm{kHz})$ seismic reflection data show abrupt termination of reflectors (Figure 7) and possible fault drag in the layered sediments [Legg, 1985]. A northeast facing scarp at the mouth of $S a n$ 


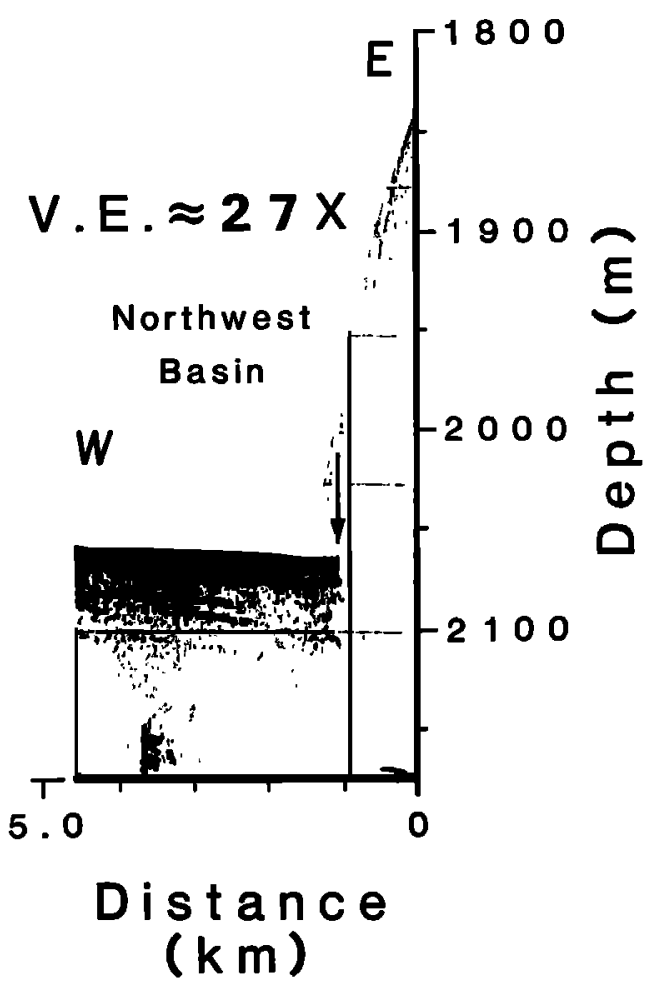

Fig. 7. High-resolution ( $3.5 \mathrm{kHz}$ ) seismic profile across the San Clemente fault in North San Clemente Basin (Northwest Basin, see Figure 3 for location of profile). Arrow identifies location of San clemente fault. Noticeable thickening of sediments toward the fault is used to estimate the rate of tectonic deepening in Northwest Basin. Northwest Basin is inferred to be a half-graben pull-apart basin, with the major subsidence occurring adjacent to the San Clemente fault.

Clemente Canyon and a southwest facing scarp along Northwest Basin lie along this same trend.

The northern segment of a major scarp, called the Junger fault, extends southeastward from San Clemente Canyon to the northern tip of Southwest Peak (SWP, Figures $2 \mathrm{~b}$ and 5). Slope gradients along this scarp are among the largest observed in the area, averaging $558\left(29^{\circ}\right)$ over an $1100-\mathrm{m}$ height; locally, the Sea Beam contours show gradients of $100 \%\left(45^{\circ}\right)$. Near-vertical slopes, with possible overhangs were observed during submersible dives in this area ( $\mathrm{J}$. Warme, personal communication, 1984). This scarp (Figure 5) turns abruptly southward where it forms the western flank of Southwest Peak (Figure 2b). This abrupt turn may represent a right step in the San Clemente fault, and the linear valley lying to the west may be interpreted as a pull-apart basin. Alternatively, the abrupt turn may represent the termination of a major branch fault at the uplifted basement structure of Fortymile Bank. Several smaller scarps are found nearer to the crest of Fortymile Bank, subparallel to the Junger fault, but there is neither a continuous scarp nor alignment of tectonic landforms along the trend of the Junger fault across Southwest Peak.

Northwest Basin is located at a right step or jog along the inferred traces of the San Clemente fault (Figures $2 b$ and 5 ). Its structure does not match the ideal pull-apart basin configuration [Crowe11, 1974]. There are no east facing fault scarps shown by the Sea Beam contours. The available, high-resolution ( $3.5 \mathrm{kHz})$ seismic reflection profiles do not show offset reflectors to indicate shallow, buried faults on the southwest side of this basin. Instead, only the northeast margin of this basin is flanked by fault scarps. Therefore we propose that this basin is an asymmetrical pull-apart basin, or half graben, bounded by a major trace of the San clemente fault to the northeast and minor, if any, faults to the southwest. Similar geologic structures have been found elsewhere in the California Continental Borderland and adjacent regions [Crowel1, 1976; Junger, 1976].

Central Segment: Northwest Basin to Triangular Basin

Along the same trend as San Clemente Canyon, a second major escarpment lies between Northwest Basin and Triangular Basin (TB, Figures $2 b$ and 5 ). This escarpment is broken by a $1-\mathrm{km}$-wide terrace which lies below Southwest Peak (Figures $2 b, 5$, and 6). The scarp below the terrace is very steep; it has an average slope gradient of about $50 \%\left(26.5^{\circ}\right)$ for its $500-\mathrm{m}$ height, and locally, Sea Beam contours show slope gradients reaching $100 \%\left(45^{\circ}\right.$; Figure 6). This lower scarp is continuous for a distance exceeding $15 \mathrm{~km}$. We have mapped the San clemente fault along this lower scarp.

Numerous small closed depressions are located at the base of the scarps. These are inferred to be sags similar to those commonly observed along terrestrial fault zones [Allen et al., 1960; Slemmons, 1977]. Some of these appear to be small pull-apart basins, located at minor offsets between en echelon fault strands, for example, the sag near the crest of Shutter Ridge (SR, Figure $2 b$ and 5). Others may be tectonic sags, where fault slip has created local depressions due to compaction of subsurface material, or minor local extension has formed small grabens or troughs. Some may have nontectonic origins.

Above the terrace, several smaller scarps are identified, subparallel to the lower scarp and en echelon to each other (Figure 6). Bulges in the Sea Beam contours that surround depressions labeled as sags represent possible slide or slump deposits. The terrace may be a partially filled hillside valley; the sags may be remnants of this valley. The numerous en echelon scarps are inferred to delineate several short surface fault traces associated with a more continuous buried zone of faulting. This buried fault zone and the San clemente fault along the base of the steep scarp below the terrace bound a long narrow fault block or tectonic sliver (Figure 5).

Two different mechanisms are proposed for the origin of the terrace and fault block: one involves predominately lateral slip; the second involves extension or transtension. According to the first hypothesis, the tectonic sliver was sheared off the flank of Fortymile Bank by right slip along the San clemente fault zone. High-resolution ( $3.5 \mathrm{kHz}$ ) seismic profiles show offset reflectors that lie along the same trend as the inferred buried fault zone [Legg, 1985] and are located on the northeast flank of the linear ridge at the northwest end of the terrace (Figures 5 and 6 ). This linear ridge would be a continuation of the fault block and therefore points to a lateral-slip mechanism. 
A second explanation for the formation of the terrace or hillside valley is backtilting of a block downfaulted from Fortymile Bank. Regional extension such as that proposed by Yeats [1976] could be responsible for such a geometry. Alternatively, local extension at a releasing bend or step in a strike-slip fault zone (transtension) could cause this downfaulting. A right step, from the Junger fault to the San Clemente fault at the base of Fortymile Bank, may account for the formation of a pull-apart basin if the San Clemente fault is a dextral wrench fault. The location of the deepest basins, and the likely location of a pull-apart basin, is to the northwest of the terrace, i.e., Northwest Basin (Figures $2 b$ and 5). Thus the extensional hypothesis seems less favorable because such basins would be expected to lie directly below the terrace and major scarp, that is, to the southwest. It is possible, however, that all of North San Clemente Basin is a large pull-apart basin and that complex block faulting between the termination of the Junger fault and the southeastward continuation of the San clemente fault have created the observed seafloor morphology.

Shutter Ridge has a broad terrace at its crest where it abuts the San Clemente fault between Northwest and Triangular basins (Figures $2 \mathrm{~b}$ and 6 ). The lateral offset mechanism proposed above also implies that Shutter Ridge is a shutteridge, i.e., it was tectonically transported into its present position by right slip along the San clemente fault. Impingement of Shutter Ridge against Fortymile Bank could break off a tectonic sliver. Alternatively, Shutter Ridge may be a large slump or slide block, and the terraces and fault scarps may be parts of a complex head scarp. Although high-resolution subbottom profiles show truncated beds exposed along the flanks and ponded sediment at the crest of Shutter Ridge [Legg, 1985], the internal structure of Shutter Ridge cannot be discerned with the these data.

At the southeast end of Shutter Ridge, the San Clemente fault follows a narrow trench along the base of the major scarp (Figures $2 b$ and 5). A linear trough, steep-sided but broader than the trench, is aligned in a more northerly trend between the northwest end of the trench and the southeast end of the filled hillside valley or terrace described above. This linear trough is reminiscent of microtopography (horst and graben?) observed along subaerial fault zones [Keller et al., 1982]. Its north-south orientation is consistent with east-west extension in a right-slip fault zone.

Triangular Basin, the site of another major right step in the generally linear trend of the San clemente fault, is also inferred to be a pull-apart basin. The San Clemente fault continues along the straight northeast margin of Triangular Basin, offset in places, and marked by subparallel and right-stepping, en echelon, southwest facing scarps of low height (Figures $2 b$ and 5 ). After stepping to the right, the fault follows a linear trough out of the southeast corner of Triangular Basin. Sma1l scarps and low mounds that bound the more irregular southern margin of Triangular Basin (Figures $2 \mathrm{~b}$ and 5) may be termination bulges like those that border other pull-apart basins (Figure 8; Freund, 1971; Sharp et al., 1982). A small basin with similar configuration is located along the San Isidro fault zone (Figure 1), about $90 \mathrm{~km}$ to the southeast of the Sea Beam area. Seismic reflection profiles across the San Isidro fault zone show that the bulge along the southern margin of this other basin is bounded by a major fault strand, which curves toward the west and dies out a few kilometers away from the basin [Legg, 1985].

Southern Segment: Triangular Basin to Navy Basin

A third segment of the San Clemente fault is delineated by a continuous line of smaller scarps that extend to the southeast from Triangular Basin (Figures 2b and 5). These scarps form the northeast flank of Navy Basin (NB). Navy Basin is equivalent to the "1868" Basin of Normark and Piper [1972] and lies at the northwest end of East San clemente Basin [Legg, 1985]. Sea Beam contours show average slope gradients of $10 \%-20 \%\left(6^{\circ}-11^{\circ}\right)$ for these scarps, although locally the scarps may be steeper. High-resolution seismic reflection profiles across Navy Basin (Figures 9b-9e) show parallel reflectors which presumably are the images of layered sediments. Late Quaternary turbidites of the Navy Fan (Figure 2a) are ponded in Navy Basin and were recovered in piston cores from this area [Normark and Piper, 1972; Normark et al., 1979]. Such seafloor lithology would be less likely to support or maintain scarps as steep as those to the northwest along the bedrock flanks of Fortymile Bank. The scarps along Navy Basin are inferred to be tectonic because of their linearity. Additional evidence supporting this interpretation is provided by the seismic profiles (Figure 9) which show offset and disrupted reflectors adjacent to the fault zone. In places, acoustic basement is juxtaposed against the well-stratified sedimentary deposits along the fault trace.

Seismic reflection profiles show the ponded Navy Fan turbidites to lie relatively downdropped in a graben between two major faults (Figure 9). One fault is evident in the Sea Beam maps as the scarp which bounds the northeast margin of Navy Basin (Figures $2 b$ and 5 ). Other seismic reflection profiles [Legg, 1985] show that the northeastern fault dies out near Navy Fan; the San Salvador Knoll trace steepens as it continues southeastward, through the sediments of Navy Fan and toward the San Isidro fault (Figure 1). The overall trend of the San Clemente fault in Navy Basin is about $5^{\circ}$ more northerly than the other major segments described above (Figures 5 and 6). Extension associated with a $5^{\circ}$ divergent segment of a dextral wrench fault could account for the subsidence. Legg [1985] proposes that Navy Basin is a long, narrow pull-apart basin located between two major, right-stepping, en echelon strands of the San clemente fault. Thus the surface expression of divergent wrench faulting is manifest here as a graben or pull-apart basin.

\section{Character of Faulting}

In well-defined wrench fault zones during advanced stages of deformation, Tchalenko [1970] observed that the displacement became concentrated on a narrow, throughgoing zone of shear, in some cases, a single shear or fault surface. He defined this zone as the principal displacement shear. In detail, he showed that the principal displacement shear is a composite of "continuous, horizontal shears" formed, as a result of continued displacement, by the connection of older shears that trend 

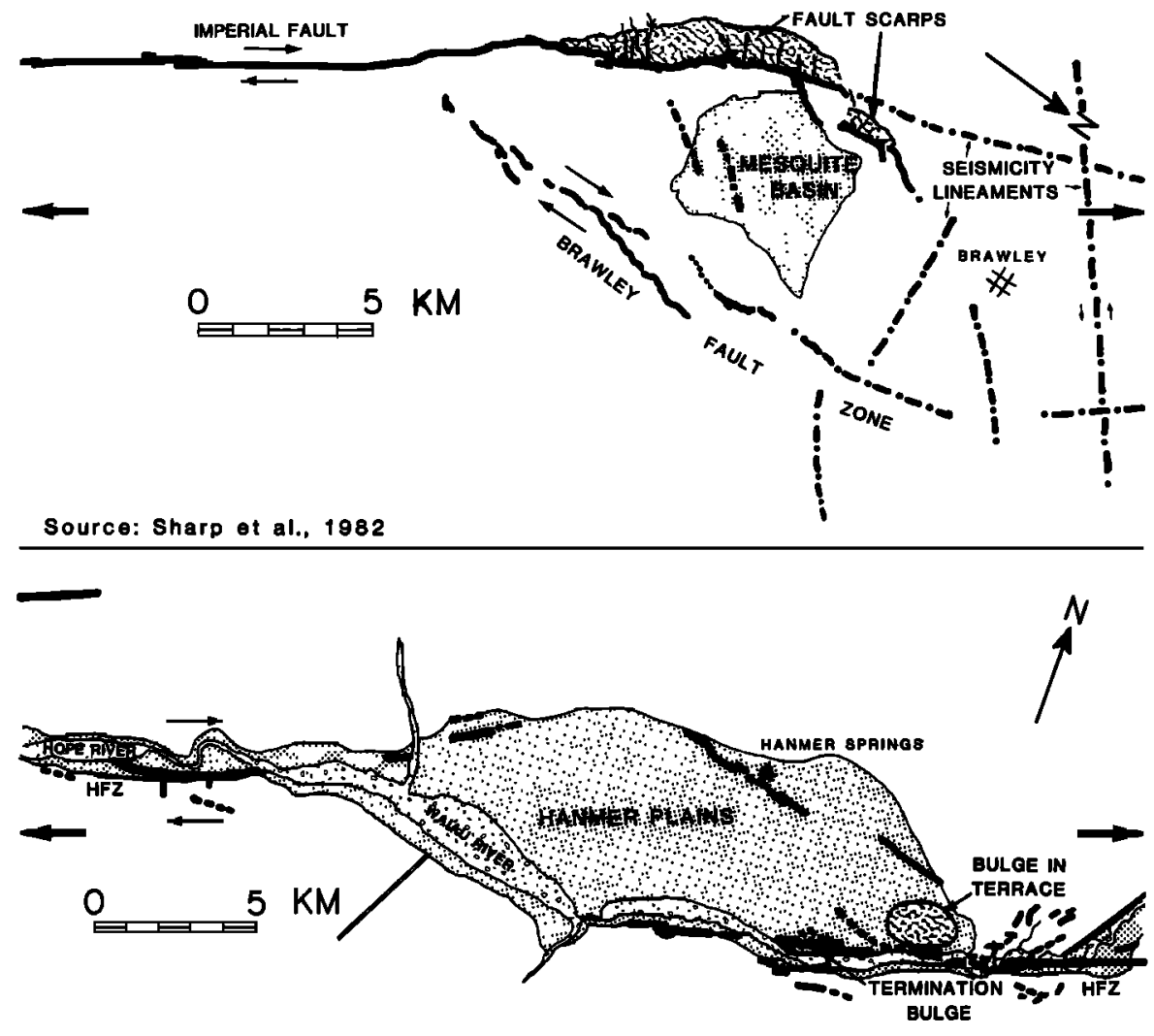

Source: Freund, 1971

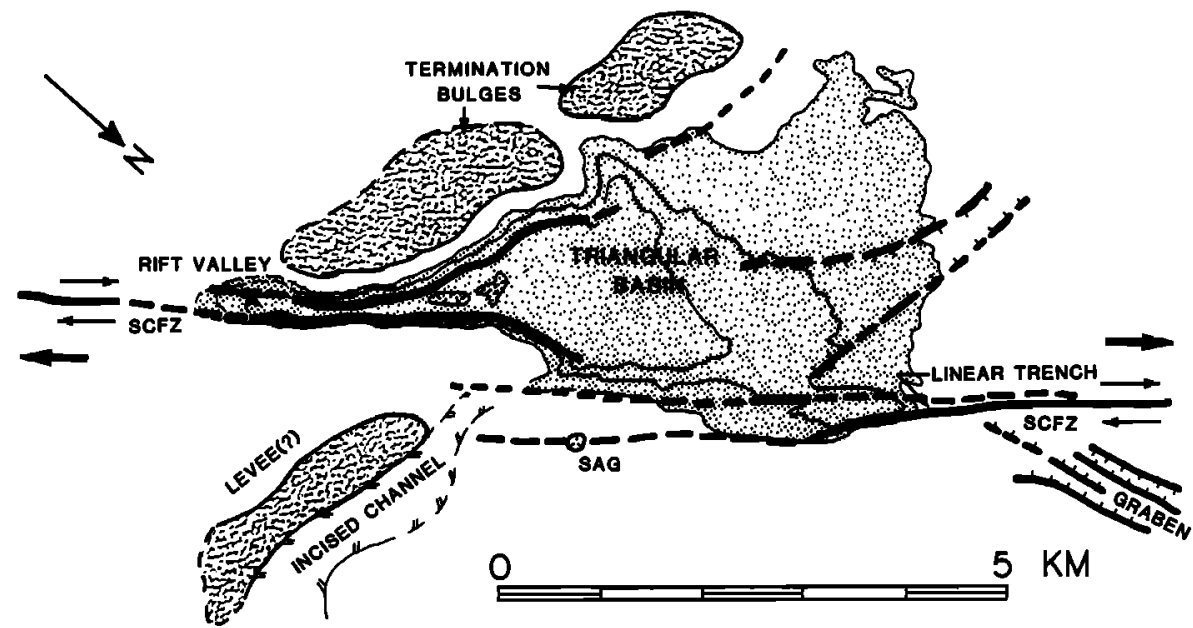

Fig. 8. Comparison of three pull-apart basins along major, dextral, wrench faults Shaded area identifies depression associated with pull-apart basin. Features possibly associated with termination bulges are shown by the other, textured pattern as labeled. (a) Mesquite Basin lies at the northern end of the Imperial fault, a major segment of the San Andreas fault system in southern California. (b) Hanmer Plains lie along the Hope fault zone (HFZ) in New Zealand. (c) Triangular Basin lies along the San Clemente fault zone (SCFZ) in the area of this study (North San Clemente Basin). Other tectonic features are also identified in the figure. All three pull-apart basins shown are associated with right steps or releasing double bends in dextral wrench faults.

slightly oblique $\left(\left\langle 5^{\circ}\right)\right.$ to the underlying master wrench fault.

The pattern of faults that form the San Clemente fault zone within North San Clemente Basin is similar to that of other major wrench fault zones in the southern California area (Figure 10). Within the wider pattern of faults that constitute the San
Clemente fault zone, Sea Beam contours show a narrow throughgoing lineament of numerous tectonic landforms that trend generally northwestward across the mapped area (San Clemente fault, Figure 5). This narrow zone $(<3 \mathrm{~km}$ wide), composed of the major fault scarps, linear trenches, and aligned sags described above, is inferred to be the main 

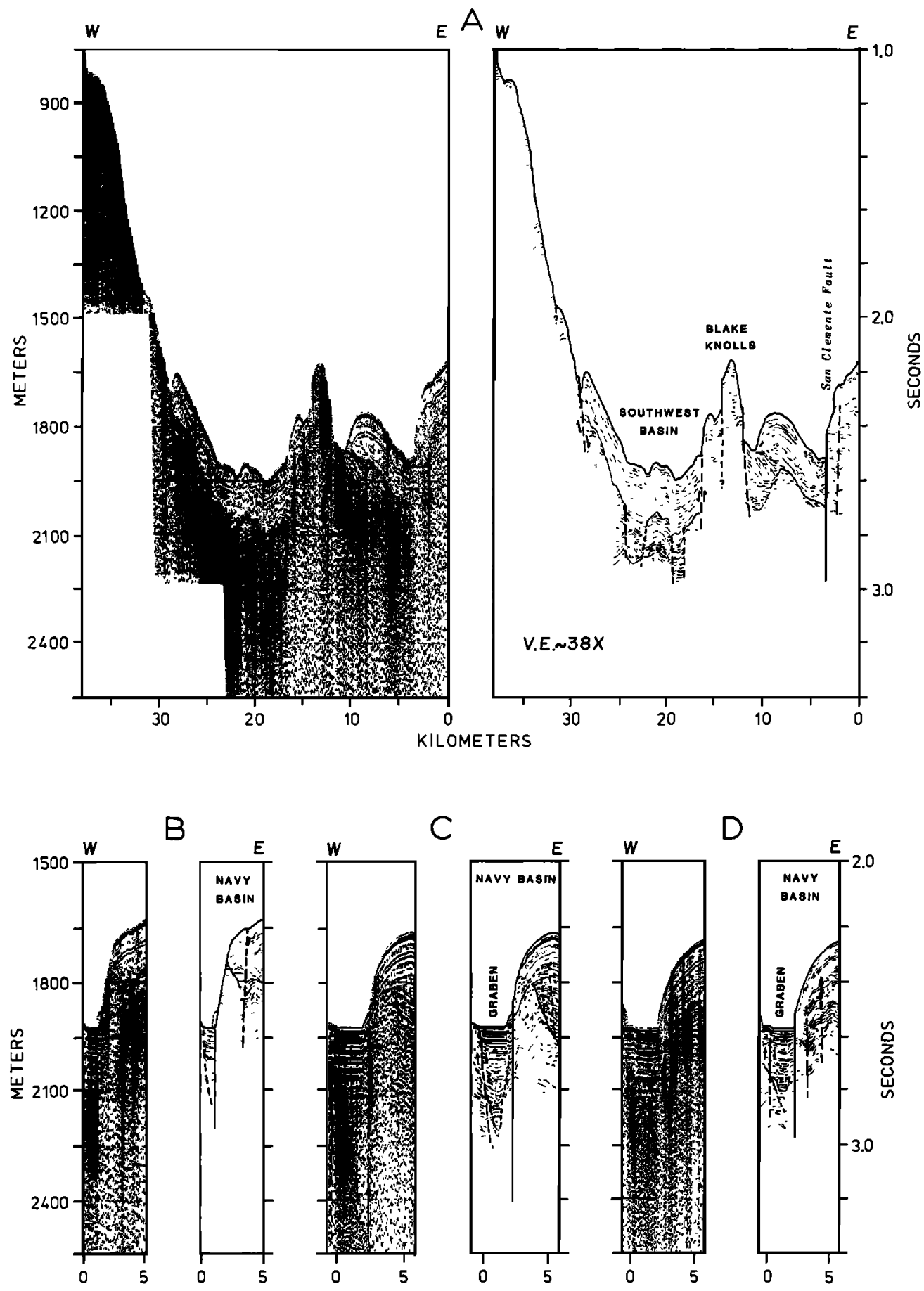

C
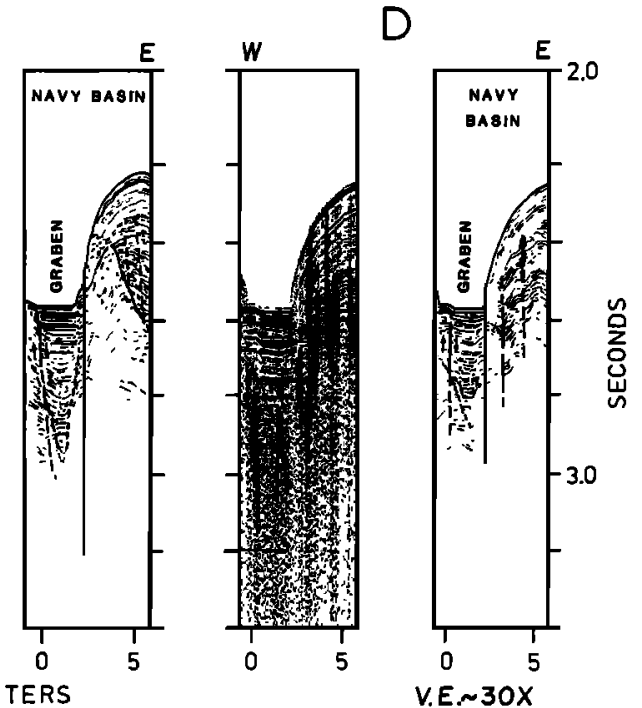

Fig. 9. High-resolution (air gun) seismic profiles across Navy Basin ("1868" Basin of Normark and Piper [1972]) and part of North San Clemente Basin (see Figures 2a and 3 for location of profiles). Line drawing interpretations show the major faults of the San Clemente fault zone in this region. (Seismic profiles courtesy of $\mathrm{J}$. Mammerickx and $P$. Lonsdale.)

fault trace or surface expression of the principal displacement shear within the San Clemente fault zone. Other lineaments of numerous tectonic landforms identified throughout the study area do not have the lateral extent, throughgoing nature, nor overall linearity of the main fault trace.

Although the large scarps in the area may be associated with substantial vertical fault move- ment, the overall straightness, and continuity of the main fault trace is more consistent with strike-slip faulting than with dip-slip faulting. The main fault trace cuts directly across the regional topography, typical of a steeply dipping fault surface. By contrast, in mountainous areas, major normal fault zones are delineated by complex, often zig-zag, fault patterns [S1emmons, 1977], 
$E$

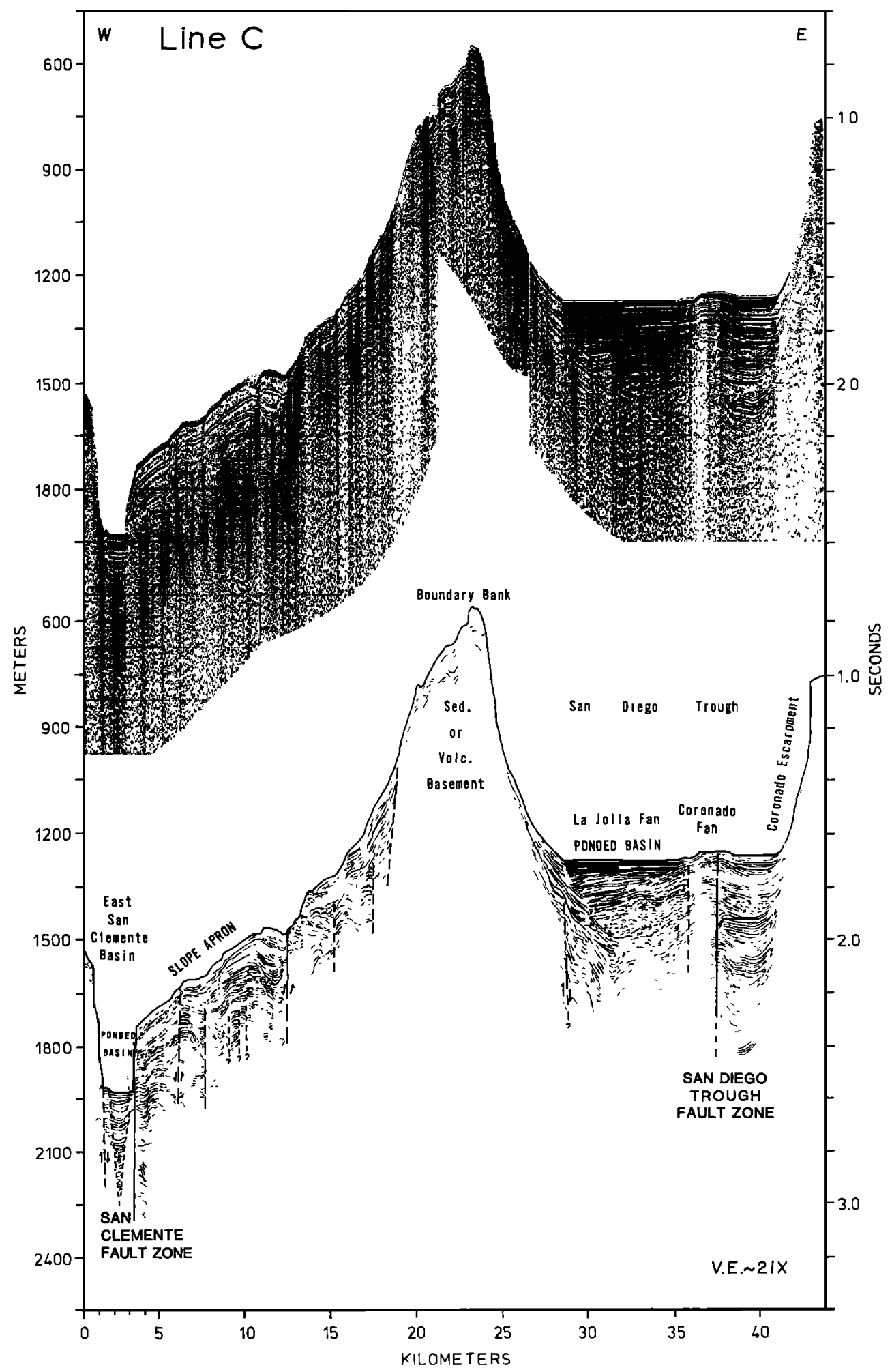

Fig. 9. (continued)

which tend to follow the topographic contours (cf. Hebgen Lake, Montana; Wasatch fault zone, Utah; and so forth). The three straight segments of the main fault trace are offset to the right at Northwest Basin and Triangular Basin. Because these basins, interpreted to be pull-apart basins, occur at right steps in the en echelon fault pattern, the San clemente fault is a right-lateral wrench fault.
Kinematics and Timing

Although rates of deposition and erosion in North San Clemente Basin are not known in detail, the abundance of geomorphic features commonly associated with active strike-slip faults (Figure 5) may be evidence of late Quaternary faulting. Low scarps in youthful sedimentary deposits are likely 


\section{Earthquake Epicenters (1977-1984)}

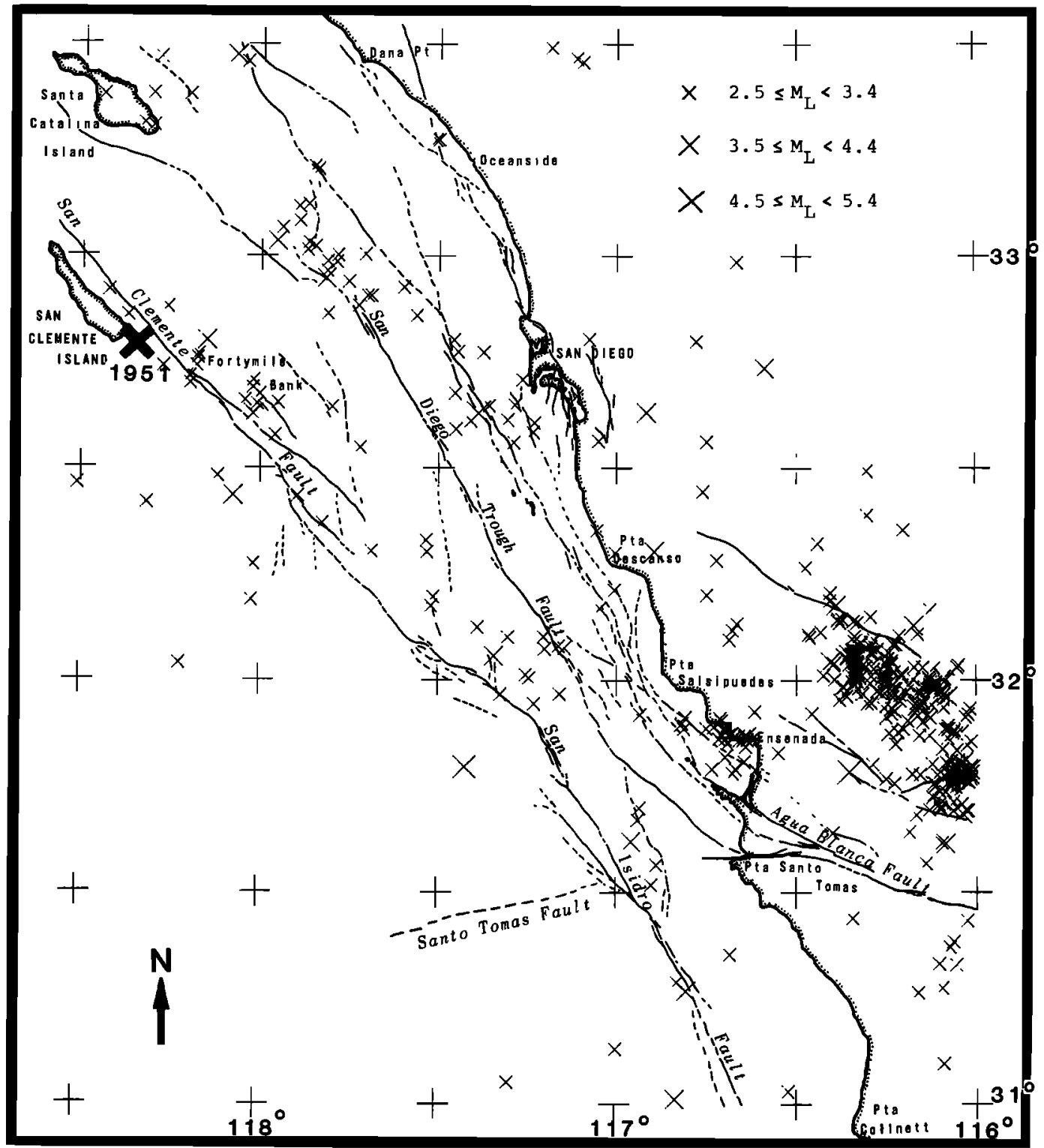

Fig. 10. Comparison of the mapped fault patterns of parts of four major dextral wrench fault zones in California. Stippling delineates areas of elevated bedrock or older sediments. Similarity in fault patterns, including continuity of principal fault segments and narrowness of the main fault zones, is characteristic of well-developed wrench faults [Wilcox et al., 1973]. All fault zones shown are mapped at the same scale.

to represent late Quaternary faulting. During a submersible dive, Lonsdale [1979] observed 1738 $\left(60^{\circ}\right)$ slope gradients along a scarp flanking the Navy submarine fan located about $20 \mathrm{~km}$ to the southeast of this area (Figure 2a). Mounds of barite associated with hydrothermal vents were also observed along the San Clemente fault zone in the area [Lonsdale, 1979]. Seafloor observations using submersibles in other areas of the California Continental Borderland showed extensive bioturbation of the upper sediments, implying that all but the most recent seafloor displacements would be obliterated [Kennedy et al., 1985].

Numerous earthquakes have occurred in the area of this study, along the trend of the San Clemente fault zone (Figure 11), but most of these are not located with sufficient accuracy to correlate with specific faults. A large earthquake (magnitude 5.9 ) occurred at the southeastern tip of San Clemente Island. Several events of moderate size, i.e., magnitude 4.0-5.0, have occurred somewhat to the east of the main traces of the San Clemente fault zone, and numerous epicenters are located near Fortymile Bank (Figure 11, cf. Legg [1980]).

High-resolution seismic profiles $(3.5-\mathrm{kHz}$ and air gun data, Figures 7 and 9) show offset or disruption of late Quaternary sedimentary deposits, including the ponded turbidites located in Navy Basin. Isopachs drawn from the high-resolution $(3.5 \mathrm{kHz}$ ) seismic profiles across Northwest Basin (Figure 7) show thickening of the sediments toward the northeast [Legg, 1985]; the thickest deposits lie adjacent to the San Clemente fault. This same character is also shown by deep penetration seismic 

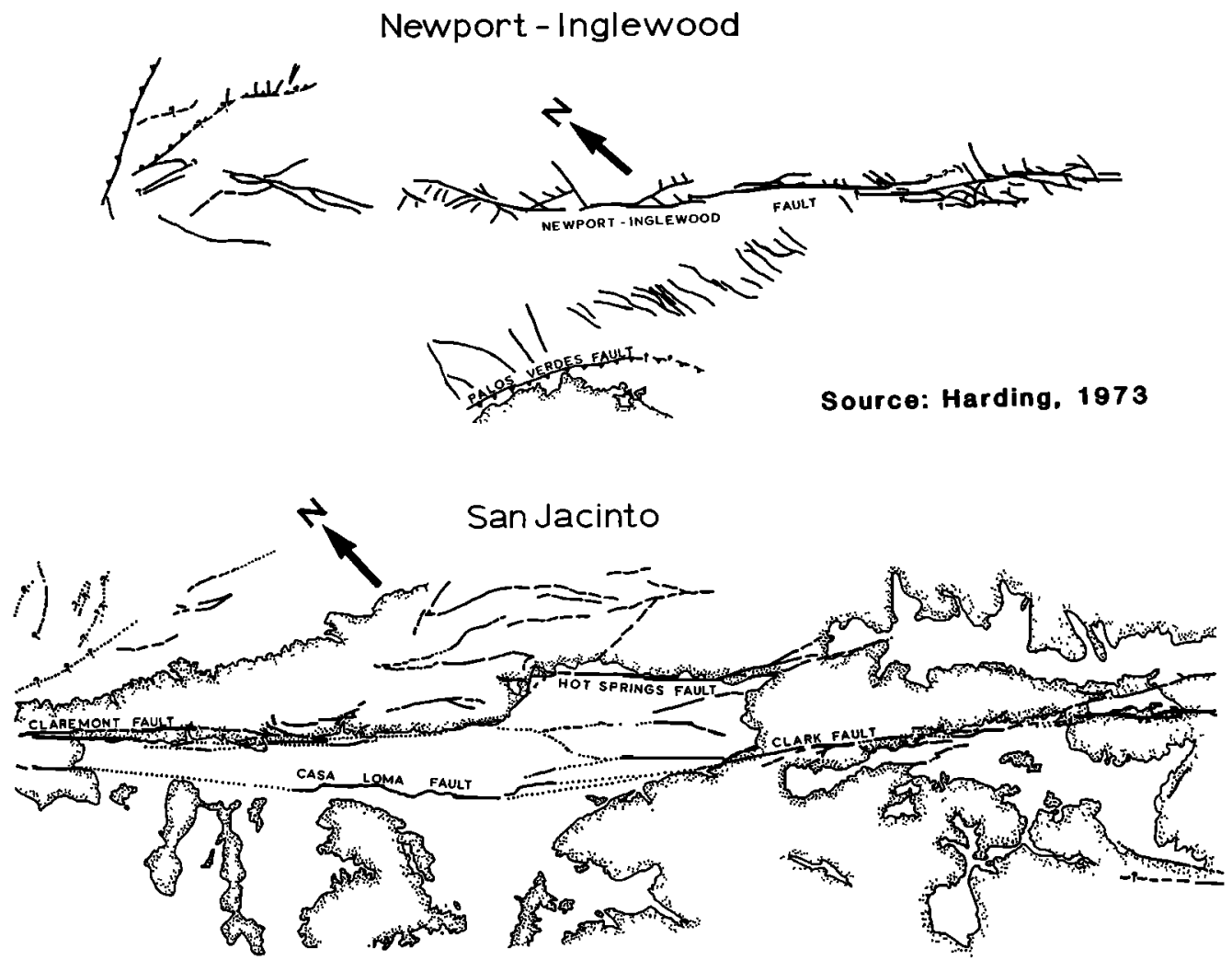

Source: CDMG, 1966

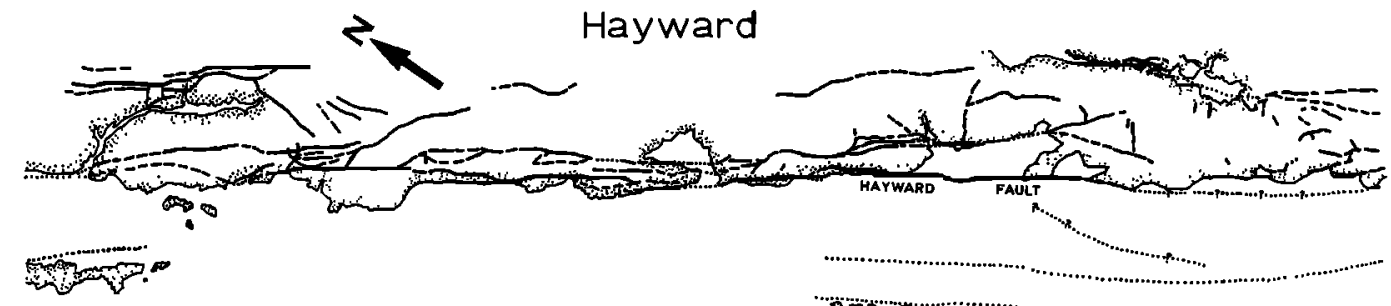

Source: CDMG, 1966

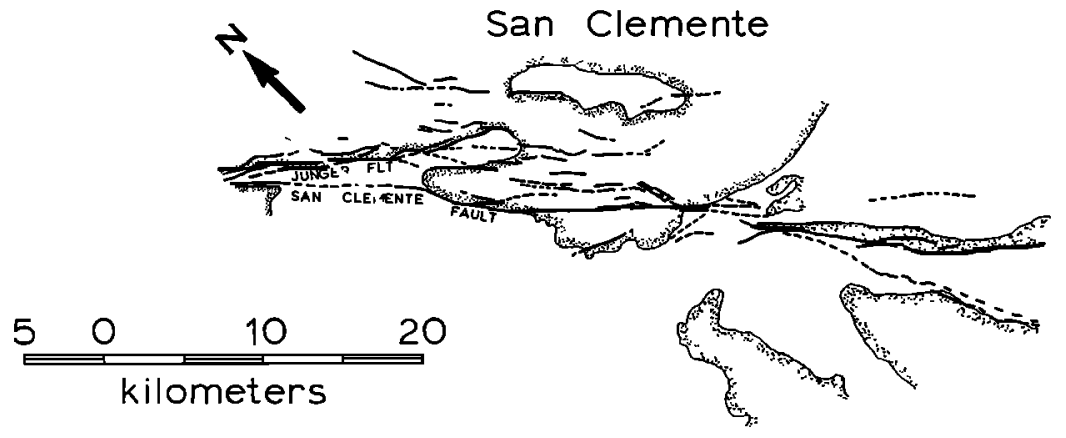

Fig. 11. Seismicity of the inner California Continental Borderland in the region surrounding this study for the period 1977-1984. Large cross near San Clemente Island marks the location of the December 26, 1951, earthquake $\left(M_{1}=5.9\right)$. Only epicenters for earthquakes with $M_{1}>2.5$ have been plotted in order to present a more homogeneous sampling of activity throughout the area. The major late Cenozoic faults are also shown for comparison with trends in the epicenters [Legg, 1985]. The greatly expanded southern California seismograph network allows recording and locating epicenters for most events with $M_{L}>2.5$ in the area for this period. The accuracy of the locations is generally poor in the offshore region, although relative locations are more reliable so that spatial trends in seismicity may show real fault trends. Data are from the California Institute of Technology seismological laboratory [Hileman et al., 1973; Legg, 1980; G. Stewart, personal communication, 1985]. 
reflection data (A. Junger and J. Vedder, personal communication, 1980). Furthermore, Sea Beam contours show aligned sags at the base of the scarp along the eastern edge of Northwest Basin (Figures $2 b$ and 5 ; cf. Plates 4 and 5 of Legg [1985]), where the sediment thickness is greatest. Thickening of the uppermost sediments and the presence of aligned sags adjacent to the fault scarp may represent continued late Quaternary subsidence of Northwest Basin, associated with movement along the fault. Legg [1985] calculates a rate of about $0.1 \mathrm{~mm} / \mathrm{yr}$ for this late Quaternary subsidence. Measured rates of uplift for Quaternary marine terraces on nearby San Clemente Island have comparable values [Muhs, 1979, 1983]. In as much as the overall structural pattern typifies wrench faulting, the rate of strike slip along the San Clemente fault zone may be substantially greater.

No lateral displacements have been measured along the San Clemente fault to date. Strike slip is difficult to determine, and recognition of "valid" piercing points under the sea is not readily accomplished. Distinctive linear submarine features such as channels, lava and debris flows, fold axes along specific horizons, canyons and fan valleys, and characteristic magnetic anomaly patterns may provide such piercing points. Sea Beam data provide detailed information on shape and continuity of seafloor mesotopography and therefore may be useful in attempts to determine components of strike-slip along major offshore faults. Carefully located bottom samples, detailed, highresolution, surface ship and near-bottom, seismic reflection surveys are required to document timing and amount of any postulated fault offsets.

\section{Conclusions}

Numerous tectonic landforms similar to those observed along active subaerial wrench faults are apparent in Sea Beam contour plots of North San Clemente Basin and the adjacent southwest flank of Fortymile Bank (Figure 5). Major scarps (10-1100 m high and 1-15 km in length), closed depressions (such as sags and small basins), and linear topography (including ridges, terraces, valleys, and other aligned depressions) are common tectonic landforms observed along the San Clemente fault zone. Sedimentary and other nontectonic(?) structural features on the seafloor can be recog-nized from the Sea Beam contours, but additional data, such as high-resolution, surface ship and nearbottom, seismic reflection profiles, bottom samples and photographs, are necessary to verify the interpretations of the seafloor geomorphology.

The San clemente fault is a dextral wrench fault. The pattern of faults which forms the San clemente fault zone within this study area is similar to that of other dextral wrench fault zones in the southern California area (Figure 10). The main trace of the San clemente fault is mapped at the base of the major scarps which separate Fortymile Bank from North San Clemente Basin (Figure 5). This zone is narrow ( $<3 \mathrm{~km}$ wide) and continuous for the entire $50-\mathrm{km}$ segment covered by the area of this study. The San Clemente fault crosses this area of rugged relief along a straight path consistent with a steeply dipping fault plane. The Junger fault, a major branch fault, splits from the main trace of the San Clemente fault in San Clemente Canyon, follows the base of a 1000-m-high escarpment, and appears to terminate at Southwest
Peak, on the flank of Fortymile Bank. A prominent secondary fault zone identified in this study, crosses a $1-\mathrm{km}$-wide terrace partway up the escarpment on the southwest flank of Southwest Peak. This fault zone is marked by numerous sags and en echelon fault scarps along the terrace.

Right-slip character is demonstrated by the systematic association of pull-apart basins with right steps or jogs in the San clemente fault. Northwest and Triangular basins are pull-apart basins, with half-graben configuration, located at the two most significant offsets in the generally straight trend of the San Clemente fault. Smaller depressions or sags are similarly associ.ted with small right steps or jogs in the fault traces. Navy Basin is a larger pull-apart basin of graben configuration, located where a more northerly trend of the San clemente fault zone and right-stepping en echelon faulting have caused local extension. Possible termination bulges at left-bending fault segments are also consistent with right slip.

The San Clemente fault zone is an active fault zone. The abundant tectonic landforms associated with the San Clemente fault zone in North San Clemente Basin are consistent with late Quaternary faulting. High-resolution seismic reflection profiles show offset or disruption of late Quaternary sedimentary sequences. Small sags and thickening of the late Quaternary sediments adjacent to the main fault trace within Northwest Basin are inferred to represent late Quaternary subsidence related to faulting. Numerous earthquake epicenters have been located in this area and show that present-day tectonic activity is occuring along the San Clemente fault zone.

The average strike $\left(\mathrm{N} 40^{\circ} \mathrm{W}\right)$ of the San Clemente fault is parallel to the predicted Pacific-North American plate boundary at this location [Minster and Jordan, 1978]. The dextral wrench fault character of the San Clemente fault is also consis. tent with faulting in the San Andreas fault system and the relative motion between the Pacific and North American lithospheric plates. Therefore we conclude that the San Clemente fault zone is a part of the larger San Andreas fault system and the Pacific-North American plate boundary. The southern California region may be considered as a broad shear zone [Legg, 1985], splintered by the many faults of the San Andreas fault system, and not attached to either the Pacific or North American plates.

Acknowledgments. The authors would like to express their gratitude to David Naar and Lynn Abbott, who assisted with the processing of the navigation for the various cruises compiled in this survey. The help of all who participated on the cruises to collect the data is also greatly appreciated. Funds for the completion of this study were provided by the office of Naval Research, the National Academy of Sciences, and NOAA Sea Grant. The careful review and numerous suggestions made by Jeff Fox, Steve Miller, John Orcutt, Gerald Schuster, George Sharman, and an anonymous reviewer helped to improve the final text of this paper and are appreciated.

\section{References}

Allen, C.R., L.T. Silver, and F.G. Stehli, The Agua Blanca fault: A major transverse structure of northern Baja California, Mexico, Geol. Soc. Am. Bu11., 71, 357-482, 1960. 
Anderson, J.G., Estimating the seismicity from geologic structure for seismic risk studies, Bu11. Seismo1. Soc. Am., 69, 135-158, 1979.

Atwater, T., Implications of plate tectonics for the Cenozoic tectonic evolution of western North America, Geol. Soc. Am. Bull., 81, 3515-3536, 1970 .

Batiza, R., D.J. Fornari, D.A. Vanko, and P. Lonsdale, Craters, calderas, and hyaloclastites on young Pacific seamounts, J. Geophys. Res., $89,8371-8390,1984$

Bird, P., and R.W. Rosenstock, Kinematics of present crust and mantle flow in southern California, Geol. Soc. Am. Bul1., 95, 946-957, 1984 .

California Division of Mines and Geology, Geologic map of California, map sheets, scale 1:250,000, Sacramento, 1966

Clark, M.M., Map showing recently active breaks along the Garlock and associated faults, California, scale 1:24,000, U.S. Geol. Surv. Misc. Geol. Invest. Map, I-741, 1973.

Crouch, J.K., Neogene tectonic evolution of the western Ttansverse Ranges and the California Continental Borderland, Geol. Soc. Am. Bull., $90,338-345,1979$.

Crouch, J.K., Northwest margin of the California Continental Borderland: Marine geology and tectonic evolution, Am. Assoc. Pet. Geol. Bu11., 65, 191-218, 1981.

Crowe11, J.C., Displacement along the San Andreas fault, California, Spec. Pap. Geol. Soc. Am. 71,1962 .

Crowell, J.C., Origin of late Cenozoic basins in southern California, Tectonics and Sedimentation, Spec. Publ. Soc. Econ. Paleontol. Minera1., 22, 190-204, 1974.

Crowell, J.C., Implications of crustal stretching and shortening of coastal Ventura Basin, California, in Aspects of the Geological History of the California Continental Borderland, Misc. Pub1. 24, edited by D.G. Howel1, Pp. 365-379, Pacific Section, American Association of Petroleum Geologists, Los Angeles, Calif., 1976.

Davis, T.L., Late Cenozoic structure and tectonic history of the western 'Big Bend' of the San Andreas Fault and adjacent San Emigdio Mountains, Ph.D. dissertation, Univ. of Calif., Santa Barbara, 1983.

Edwards, M.H., R.E. Arvidson, and E.A. Guinness, Digital image processing of Seabeam bathymetric data for structural studies of seamounts near the East Pacific Rise, J. Geophys. Res., 89, $11,108-11,116,1984$.

Engebretson, D.C., A. Cox, and R.G. Gordon, Relative motion between the oceanic and continental plates in the Pacific basin, Spec. Pap. Geol. Soc. Am., 206, 59 pp., 1985.

Field, M.E., B.D. Edwards, N. Kenyon, M. Somers, and R.N. Hey, Volcanic and depositional patterns on the seafloor off southern California as seen by GLORIA side-scan sonar, Eos Trans. AGU, 65 , 1083, 1984.

Freund, R., The Hope fault: A strike-slip fault in New Zealand, N.Z. Geo1. Surv. Bu11., 86, 49 pp., 1971

Gallo, D.G., P.J. Fox, and K.C. Macdonald, A Sea Beam investigation of the Clipperton Transform fault: The morphotectonic expression of a fast slipping transform boundary, J. Geophys. Res., 91, 3455-3467, 1986

Greene, H.G., K.A. Bailey, S.H. Clarke, J.I. Ziony, and M.P. Kennedy, Implications of fault patterns of the inner California Continental Borderland between San Pedro and San Diego, in Earthquakes and Other Perils: San Diego Region, edited by P.L. Abbott and W.J. Elliott, pp. 21-27, San Diego Association of Geologists, San Diego, Calif., 1979

Hanks, T.C., R.C. Bucknam, K.R. Lajoie, and R.E. Wallace, Modification of wave-cut and faulting-controlled landforms, J. Geophys. Res., 89, $5771-5790,1984$.

Harding, T.P., Newport-Inglewood trend, CaliforniaAn example of the wrench style deformation, Am. Assoc. Pet. Geo1. Bul1., 57, 97-116, 1973.

Hileman, J.A., C.R. Allen, and J.M. Nordquist, Seismicity of the southern California region, 1 January, 1932 to 31 December, 1972, Contrib. 2385, Div. of Geol. and Planet. Sci., Calif. Inst. of Techno1., Pasadena, 1973.

Hornafius, J.S., B.P. Luyendyk, R.R. Terres, and M.J. Kamerling, Timing and extent of Neogene tectonic rotation in the western Transverse Ranges, California, Geol. Soc. Am. Bull., 97, $1476-1487,1986$.

Howe11, D.G., A model to accommodate 1000 kilometers of right-slip in the southern California area, in Aspects of the Geological History of the California Continental Borderland, Misc. Pub1. 24, edited by D.G. Howell, PP. 530-540, Pacific Section, American Association of Petroleum Geologists, Los Angeles, Calif., 1976.

Howe11, D.G., and M.H. Link, Eocene conglomerate sedimentology and basin analysis, San Diego and the southern California Borderland, J. Sediment. Petrol., 49, 517-540, 1983.

Howell, D.G., C.J. Stuart, J.P. Platt, and D.J Hill, Possible strike-slip faulting in the southern California Borderland, Geology, 2 , 93-98, 1974a.

Howell, D.G., C.J. Stuart, J.P. Platt, and D.J. Hil1, Reply, Geology, 3, 3-4, 1974b.

Junger, A., Tectonics of the southern California Borderland, in Aspects of the Geological History of the California Continental Borderland, Misc. Pub1. 24, edited by D.G. Howel1, Pp. 486-498, Pacific Section, American Association of Petroleum Geologists, Los Angeles, Calif., 1976.

Kastens, K.A., W.B.F. Ryan, and P.J. Fox Structural and volcanic expression of a fast slipping ridge-transform-ridge-plate boundary: Sea MARC I and Photographic surveys at the Clipperton Transform fault, J. Geophys. Res., $91,3469-3488,1986$.

Keller, E.A., M.S. Bonkowski, R.J. Korsch, and R.J. Shlemon, Tectonic geomorphology of the San Andreas fault zone in the southern Indio Hills, Coachella Valley, California, Geol. Soc. Am. Bul1., 88, 46-56, 1982.

Kennedy, M.P., S.H. Clarke, H.G. Greene, and M.R. Legg, Recency and character of faulting offshore metropolitan San Diego, California, Map Sheet 42, scale 1:50,000, Calif. Div. Mines and Geol., Sacramento, 1980

Kennedy, M.P., S.H. Clarke, H.G. Greene, and P.F. Lonsdale, Observations from DSRV Alvin of Quaternary faulting on the southern California continental margin, U.S. Geol. Surv. Open File Rep. 85-39, 1985.

Kies, R.P., and P.L. Abbott, Rhyolite clast populations and tectonics in the California Continental Borderland, Geol. Soc. Am. Bull., $88,1553-1566,1983$. 
Lawson, A.C., et. al., The California earthquake of April 18, 1906: Report of the state earthquake investigation commission, 2 volumes and atlas, Carnegie Inst., Washington, D.C., 1908.

Legg, M.R., Seismicity and tectonics of the inner continental borderland of southern California and northern Baja California, Mexico, M.S. thesis, Univ. of Calif., San Diego, 1980.

Legg, M.R., Geologic structure and tectonics of the inner continental borderland offshore northern Baja California, Mexico, Ph.D. dissertation, Univ. of Calif., Santa Barbara, 1985.

Legg, M.R., and M.P. Kennedy, Faulting offshore San Diego and northern Baja California, in Earthquakes and Other Perils: San Diego Region, edited by P.L. Abbott and W.J. Elliott, Pp. 29-46, San Diego Association of Geologists, San Diego, Calif., 1979 .

Lonsdale, P., A deep-sea hydrothermal site on a strike-slip fault, Nature, 281, 531-534, 1979.

Macdonald, K., J.C. Sempere, and P.J. Fox, East Pacific Rise from Siqueiros to Orozco fracture zones: Along strike continuity of axial neovolcanic zone and structure and evolution of overlapping spreading centers, J. Geophys. Res., $89,6049-6069,1984$

Madsen, J.A., P.J. Fox, and K.C. Macdonald, Morphotectonic fabric of the Orozco Transform Fault: Results from a Sea Beam investigation, $J$. Geophys. Res., 91, 3439-3454, 1986.

Mammerickx, J., The morphology of propagating spreading centers: New and old, J. Geophys. Res., 89, 1817-1828, 1984.

Minster, J.B., and T.H. Jordan, Present-day plate motions, J. Geophys. Res., 83, 5331-5334, 1978.

Moore, D.G., Reflection profiling studies of the California Continental Borderland: Structure and Quaternary turbidite basins, Spec. Pap. Geol. Soc. Am. 107, 1969

Muhs, D.R., Marine terrace age assignments, uplift rates and sea level events on San clemente Island, California, Geol. Soc. Am. Abstr. Programs, 11, 484, 1979.

Muhs, D.R., Quaternary sea-level events on northern San Clemente Island, California, Quat. Res., 20, $322-341,1983$.

National Ocean Service, Bathymetric map of the California Continental Borderland, sheets $1206 \mathrm{~N}-15$ and -16 , scale 1:250,000, Riverdale, Md. 1974.

Normark, W.R., and D.J.W. Piper, Sediments and growth pattern of Navy deep-sea fan, San Clemente basin, California, J. Geol., 80, $198-223,1972$

Normark, W.R., D.J.W. Piper, and G.R. Hess, Distributary channels, sand lobes and mesotopography of Navy Submarine Fan, California Borderland, with applications to ancient fan sediments, Sedimentology, 26, 749-774, 1979.

Patterson, R.H., Tectonic geomorphology and neotectonics of the Santa Cruz Island fault, Santa Barbara County, California, M.A. thesis, Univ. of Calif., Santa Barbara, 1979.

Renard, V., and J.P. Allenou, Sea Beam, multi-beam echo-sounding in "Jean Charcot", Int. Hydrogr. Rev., 56, 35-67, 1979.

Ridlon, J.B., San Clemente Island Rocksite Project: offshore geology, part 2, Reconnaissance survey around the island, report, Nav. Undersea Res. and Dev. Cent., San Diego, Calif., 1969.
Searle, R.C., Side-scan sonar studies of the North Atlantic fracture zones, J. Geol. Soc. London, $136,283-292,1979$.

Sharp, R.V., et al., Surface faulting in the central Imperial Valley, The Imperial Valley, California, earthquake of October $15,1979, U . S$. Geo1. Surv. Prof. Pap., 1254, 119-143, plate 1, 1982.

Shepard, F.P., and K.O. Emery, Submarine topography of the southern California coast: Canyons and tectonic interpretation, Spec. Pap. Geol. Soc. An. , 31, 1941

Silver, E.A., N.A. Breen, H. Prasetyo, and D.M. Hussong, Multibeam study of the Flores back arc thrust belt, Indonesia, J. Geophys. Res., 91, 3489-3500, 1986 .

Slemmons, D.B., Faults and earthquake magnitude, report 6, State of the Art for Assessing Earthquake Hazards in the United States, Misc. Pap. $S-73-1$, U.S. Army Corps Eng., Vicksburg, Miss., 1977.

Spiess, F.N., and R.C. Tyce, Marine Physical Laboratory Deep Tow instrumentation system, Ref. 73-4, Scripps Inst. Oceanog., La Jolla, Calif., 1973 .

Tchalenko, J.S., Similarities between shear zones eof different magnitudes, Geol. Soc. Am. Bull., $81,1625-1640,1970$.

Vedder, J.G., I.A. Beyer, A. Junger, G.W. Moore, A.E. Roberts, J.C. Taylor, and H.C. Wagner, Preliminary report on the geology of the continental borderland of southern California, scale 1:500,000, U.S. Geol. Surv. Misc. Field Stud. Map, $M F-624,1974$.

Weldon, R.J., II, and E. Humphreys, A kinematic model of southern California, Tectonics, 5, $33-48,1986$.

Weldon, R.J., II, and K.E. Sieh, Holocene rate of slip and tentative recurrence interval for large earthquakes on the San Andreas fault, Cajon Pass, southern California, Geol. Soc. Am. Bull., $96,793-812,1985$.

Wilcox, R.E., T.P. Harding, and D.R. Seeley, Basic wrench tectonics, Am. Assoc. Pet. Geol. Bull., 57, 74-96, 1973 .

Yeats, R.S., Extension versus strike-slip origin of the southern California Borderland, in Aspects of the Geological History of the California Continental Borderland, Misc. Pub1. 24 , edited by D.G. Howell, pp. $455-485$, Pacific Section, American Association of Petroleum Geologists, Los Angeles, Calif., 1976.

C. de Moustier and J. Mammerickx, Scripps Institution of Oceanography, University of California, San Diego, CA 92093.

M. R. Legg, NTS Engineering, 6695 E. Pacific Coast Highway, Long Beach, CA 90803.

B. P. Luyendyk, Department of Geological Sciences, University of California, Santa Barbara, CA 93106 .

R.C. Tyce, Graduate School of Oceanography, University of Rhode Island, Kingston, RI 02882.

(Received August 4, 1986

revised May 9, 1988; accepted September 5, 1988.) 